\title{
Potential Cardiovascular Effects of the Glucagon-like Peptide-1 Receptor Agonists
}

\section{Robert J Chilton*}

Department of Medicine, Division of Cardiology, The University of Texas Health Science Center at San Antonio, San Antonio, Texas 78229, USA

\begin{abstract}
In patients with type 2 diabetes, cardiovascular risk reduction represents an important clinical goal in light of the elevated risk of cardiovascular mortality in this patient population; thus, it is important that glucose-lowering drugs have no negative effects and potentially some positive effects on cardiovascular risk. The glucagon-like peptide-1 receptor agonists (GLP-1RAs), which were designed to resist degradation by the enzyme dipeptidyl peptidase-4, are among the newer glucose-lowering agents for the treatment of type 2 diabetes. There are a number of agents within this class, including exenatide, liraglutide, albiglutide, lixisenatide, and dulaglutide. Preclinical research efforts in animal models have identified a number of favorable cardiovascular effects of GLP-1RAs beyond glucose lowering. Although the underlying basis for these cardiovascular effects has not yet been elucidated, a number of potential mechanisms have been suggested. Accumulating data from randomized clinical trials and retrospective/post hoc pooled analyses of clinical trials support the favorable effects of GLP-1RAs on blood pressure and lipid profiles. Although some observations have suggested that GLP-1RAs may lead to an increase in heart rate, a recent post hoc analysis including 11 studies of exenatide once weekly versus active comparators or placebo shows that mean increases in heart rate are small and transient, increases are more common in patients with low baseline heart rate, and that heart rate elevations become less prevalent over time. In addition, no association was observed between major adverse cardiac events and small mean increases in heart rate. Individual clinical trials in patients with type 2 diabetes also have provided evidence of protection against post-myocardial infarction ischemic damage, as well as the ability to improve circulating biomarker levels. Forthcoming data from phase 3 and 4 cardiovascular outcome trials of GLP-1RAs will provide further insight into their cardiovascular safety and cardioprotective potential in various settings.
\end{abstract}

Keywords: Albiglutide; Blood pressure; Cardiovascular disease; Dulaglutide; Exenatide; Glucagon-like peptide-1 receptor agonists; Liraglutide; Lixisenatide

Abbreviations: BNP: B-type (brain) Natriuretic Peptide; BP: Blood Pressure; bpm: beats per minute; DBP: Diastolic Blood Pressure; DPP-4: Dipeptidyl Peptidase-4; GLP-1: Glucagon-Like Peptide-1; GLP-1RA: Glucagon-Like Peptide-1 Receptor Agonist; HDL: HighDensity Lipoprotein; hsCRP: high-sensitivity C-Reactive Protein; LDL: Low-Density Lipoprotein; LS: Least Squares; LV: Left Ventricular; MACE: Major Adverse Cardiac Events; MDI: Multiple Daily Insulin; MI: Myocardial Infarction; pPCI: primary Percutaneous Coronary Intervention; SBP: Systolic Blood Pressure; STEMI: ST-SegmentElevation Myocardial Infarction; VLDL: Very Low-Density Lipoprotein

\section{Introduction}

Cardiovascular risk reduction is a fundamental component of the management of type 2 diabetes, with the recognition that cardiovascular disease accounts for more than half of the mortality in this patient population [1-4]. The development and progression of cardiovascular disease are particularly aggressive in patients with type 2 diabetes, for which proposed mechanisms include an underlying effect of hyperglycemia on endothelial cell dysfunction, development of a prothrombotic state, and/or negative arterial modeling [5]. In patients with diabetes, a 3 -fold increase in cardiovascular mortality and significantly higher 30-day and 1-year mortality after presentation with acute coronary syndrome, have been reported, compared with patients without diabetes [6]. Specifically, glycemic control has been shown to be a key element in reducing cardiovascular risk in patients with type 2 diabetes $[7,8]$. Long-term randomized controlled trials studies such as VADT (Veterans Administration Diabetes Trial) [9], ADVANCE (Action in Diabetes and Vascular Disease: Preterax and Diamicron
Modified Release Controlled Evaluation) [10] and ACCORD (The Action to Control Cardiovascular Risk in Diabetes) [11] have shown that strict glycemic control is not associated with significant benefit in terms of cardiovascular outcomes in patients with type 2 diabetes and may even increase the risk of adverse cardiovascular outcomes and mortality in elderly patients at high cardiovascular risk [12]. Although increased incidence of hypoglycemia was observed with intensive antiglycemic treatment in all three studies, there is insufficient data to show causality between it and higher cardiovascular mortality in patients under strict glycemic control [12]. Notably, in 2007, rosiglitazone was shown to be associated with increased risk of myocardial infarction and cardiovascular-related mortality [13] and, as a result, changes were made to the regulatory requirements for development of antidiabetic drugs in 2008 requiring that clinical studies ruled out excess cardiovascular risk [14].

Overall, it is apparent that diabetes can be regarded as a cardiovascular disease, not just a comorbid condition that often coexists with cardiovascular disease [15]. Accordingly, it is critical that

*Corresponding author: Professor. Robert J Chilton, Department of Medicine, Division of Cardiology, The University of Texas Health Science Center at San Antonio, 7703 Floyd Curl Drive, San Antonio, Texas 78229, USA, Tel: 210-279 1248; E-mail: Chilton@uthscsa.edu

Received September 26, 2014; Accepted December 22, 2014; Published January 05, 2015

Citation: Chilton RJ (2015) Potential Cardiovascular Effects of the Glucagonlike Peptide-1 Receptor Agonists. J Diabetes Metab 6: 483. doi:10.4172/21556156.1000483

Copyright: @ 2015 Chilton RJ. This is an open-access article distributed under the terms of the Creative Commons Attribution License, which permits unrestricted use, distribution, and reproduction in any medium, provided the original author and source are credited. 
glucose-lowering agents do not increase cardiovascular risk, and the ability to produce positive cardiovascular effects beyond those afforded by glucose control would be optimal [16].

Glucagon-like peptide-1 (GLP-1) is released into the circulation as an effect of food intake and is rapidly degraded by the enzyme dipeptidyl peptidase-4 (DPP-4), with a reduced postprandial response to this peptide hormone implicated in the pathogenesis of type 2 diabetes [17]. GLP-1 receptor agonists (GLP-1RAs) are resistant to the effects of DPP-4 and represent a relatively new class of glucose-lowering agents $[18,19]$. In patients with diabetes, these agents act to lower glucose by enhancing pancreatic $\beta$-cell-mediated glucose-dependent insulin secretion, suppressing glucagon secretion in the setting of abnormally high levels, delaying gastric emptying, and reducing food intake. Some potential benefits over other glucose-lowering agents have been recognized, including weight loss and a lower (albeit not eliminated) risk of hypoglycemia [18]. A number of GLP-1RAs are currently available or under investigation [20], including exenatide (twice daily or once weekly), liraglutide (once daily), and albiglutide (once weekly), which are indicated with diet and exercise for the improvement of glycemic control in adults with type 2 diabetes in the United States. Lixisenatide (once daily) is available in countries outside the United States, and other agents are in late-stage development (eg, dulaglutide). Effects of this class are known to extend beyond glucose lowering and include a number of potential cardiovascular benefits including small reductions in blood pressure (BP), potential effects on lipid and circulating biomarker profiles, and protection against post-myocardial infarction (MI) damage, which are discussed herein.

\section{Materials and Methods}

A series of literature searches were conducted of the PubMed.gov database in November 2013 (with no limits on publication dates) to identify both preclinical and randomized clinical trials of the GLP-1RAs with the most extensive clinical experience, exenatide and liraglutide. For this review, focus was placed on the key Phase 3 clinical trial data for the GLP1-RAs, although all clinical data with cardiovascular outcomes were considered for inclusion. The search terms used were: 1) (randomized controlled trial) and (glucagon-like peptide-1 receptor agonist OR GLP-1RA or exenatide OR liraglutide) and (type 2 diabetes) and (cardiovascular), human only; and 2) (preclinical OR animal) and (glucagon-like peptide-1 receptor agonist OR GLP-1RA or exenatide OR liraglutide); with no other limits applied. In June 2014, a new search was conducted to capture additional clinical trials for GLP1RAs, specifically albiglutide, lixisenatide, and dulaglutide using the same search strategy. Another supplementary literature search was performed in November 2014 to update the literature immediately prior to publication. After a manual review of the search results and selection of individual articles providing cardiovascular data, results were supplemented with reports of interest from bibliographies of published papers or key data from published abstracts or associated presentations.

Ongoing trials relevant to this topic were identified using the U.S. National Institutes of Health ClinicalTrials.gov registry.

\section{Preclinical data and potential mechanisms for the cardiovascular effects of GLP-1RA agents}

Substantial preclinical evidence supports that GLP-1RAs improve $\mathrm{BP}$, with additional effects that may include improved myocardial metabolism, coronary blood flow, pre-/post-ischemic conditioning, Left Ventricular (LV) remodeling, and LV performance (as recently reviewed elsewhere) [15]. A vast amount of preclinical literature derived from animal models collectively supports that GLP-1 receptor (GLP-1R) stimulation may culminate in a broad range of physiological effects involving the blood vessels (and the heart , as well as the nervous system, intestines, and kidneys [17]. Importantly, the effects of GLP1RAs on blood vessels and the heart appear to be reflective of the localization of GLP-1 receptors and direct effects on these organs.

Preclinical trials focused on elucidating the effects of GLP-1 on BP and heart rate collectively support significant effects on these parameters [21-26]. An early study in male Sprague-Dawley rats found dose-dependent increases in BP (including systolic BP (SBP) and diastolic BP (DBP)) as well as heart rate with both GLP-1 (7-36) amide and exendin-4, with more rapid and strong effects for the former and more prolonged effects for the latter [21]. Exendin-(9-36) exhibited antagonist effects, blocking the increases in both $\mathrm{BP}$ and heart rate, when co-administered with GLP-1 (7-36) amide and exendin-4supporting the hypothesis that this effect is receptor mediated.

Numerous preclinical investigations of the effects of GLP-1 in animal models of MI have provided evidence of improvements in infarct size and cardiac function [27-33], with no deleterious histopathological effects on the pancreas [34-36].

Some findings may provide insight into the cardioprotective mechanisms underlying the changes in infarct size and cardiac function, including increased myocardial expression of phosphorylated protein kinase B (pAkt), reduction in active caspase 3 expression, increased antioxidant enzyme activity and reduced nuclear oxidative stress with active treatment [31]. One of the more recent trials focused on elucidating the effects of GLP-1 in neutrophil-mediated reperfusion injury, with GLP-1 administration immediately prior to reperfusion resulting in a significant reduction in infarct size as well as neutrophil activation in blood and myocardial accumulation [33].

In addition to those described above, a number of potential cardioprotective mechanisms for GLP-1 have been described (Figure 1) [37], such as a potential effect on myocardial glucose uptake and a number of other myocardial and systemic effects that may stem from its activity in the gastrointestinal system, adipose tissue, and/or vascular system $[37,38]$. GLP-1 has been proposed to have a direct influence on endothelial cells by means of GLP-1R, with anti-inflammatory effects reflecting a reduction in expression of the receptor for advanced glycation end products $[39,40]$. The mechanism(s) of BP reduction for GLP-1RAs, involve GLP-1R activation leading to atrial natriuretic peptide secretion and subsequent BP reduction (Figure 2) [41]. Anti-atherosclerotic effects of GLP-1 may be mediated via reduced monocyte/macrophage accumulation in the arterial wall, by inhibiting the inflammatory response in macrophages [42], whereas effects on survival and infarct remodeling post-MI may reflect activation of cardioprotective signaling pathways in the heart [29].

\section{Clinical Trial Data: Cardiovascular Effects}

\section{Vital signs}

BP data from the Diabetes therapy Utilization: Researching changes in A1c, weight and other factors Through Intervention with exenatide ONce weekly (DURATION) trials of exenatide once weekly [43-52] and the Liraglutide Effect and Action in Diabetes (LEAD) studies of liraglutide [53-60] are summarized in Table 1. Overall, the DURATION and LEAD studies collectively support that exenatide once weekly and liraglutide confer SBP reductions from baseline, 
Citation: Chilton RJ (2015) Potential Cardiovascular Effects of the Glucagon-like Peptide-1 Receptor Agonists. J Diabetes Metab 6: 483. doi:10.4172/2155-6156.1000483

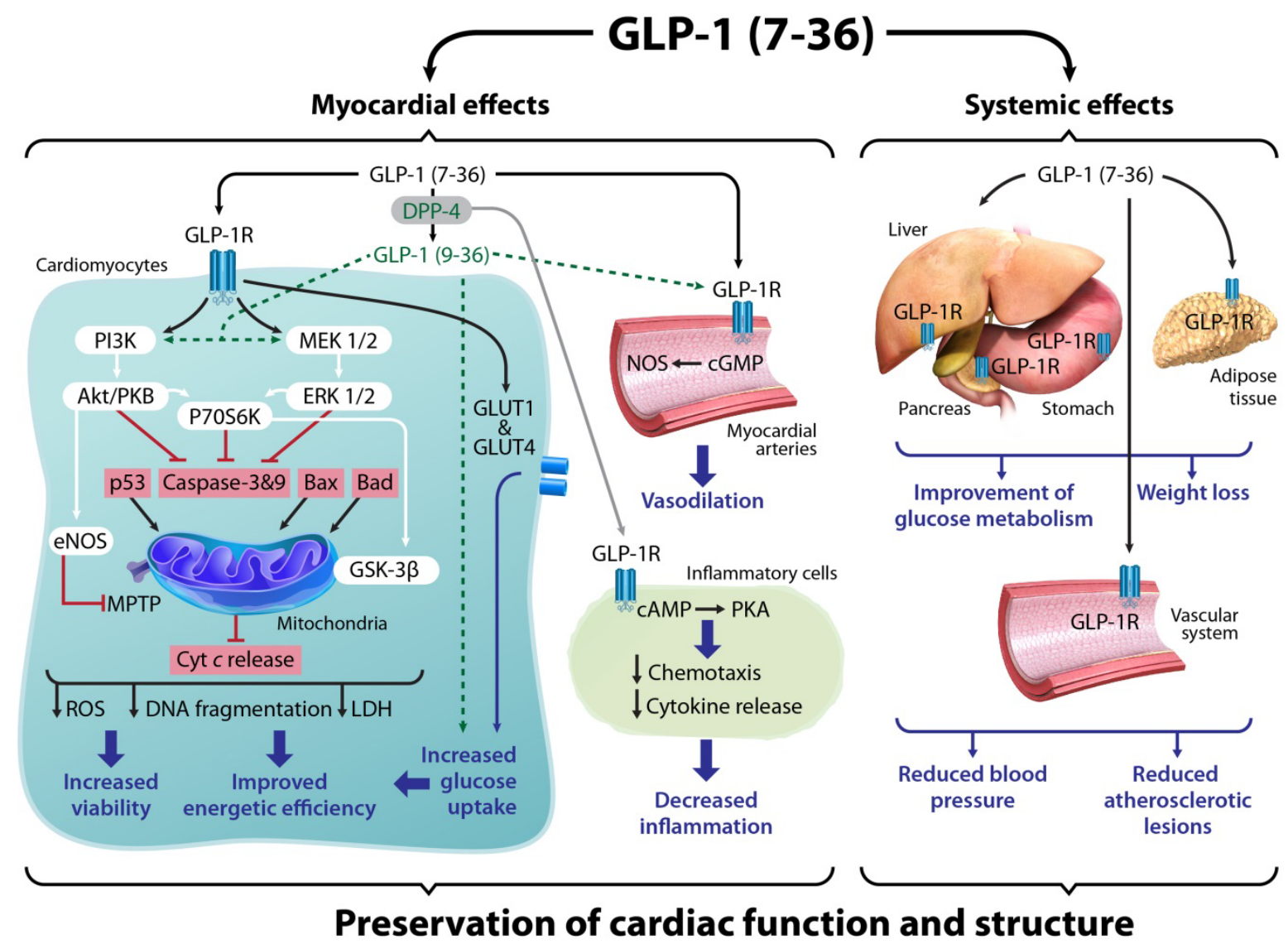

Figure 1: Schematic representation of the proposed pathways by which GLP-1 may exert its cardiovascular actions. The combination of GLP-1 effects on the myocardium (ie, apoptosis and necrosis prevention in cardiomyocytes through the activation of the RISK pathway, increased glucose metabolism, vasodilatory and anti-inflammatory actions) with GLP-1 metabolic and vascular effects at the systemic level contributes to cardiac survival and function improvement. cAMP: cyclic adenosine monophosphate; cGMP: cyclic guanosine monophosphate; Cyt c: cytochrome c; DPP-4: dipeptidyl peptidase-4; ERK: extracellular signal-regulated kinase; GLP-1: glucagon-like peptide-1; GLP-1R: GLP-1 receptor; GLUT: glucose transporter; GSK: glycogen synthase kinase; LDH: lactate dehydrogenase; MEK1/2: MAP kinase; MPTP: mitochondrial permeability transition pore; NOS: nitric oxide synthase; PI3K: phosphatidylinositol 3-kinase; PKA: protein kinase A; PKB: protein kinase B; ROS: reactive oxygen species. Reprinted with permission from Ravassa et al. Cardiovasc Res. 2012;94(2): 316-323 [37].

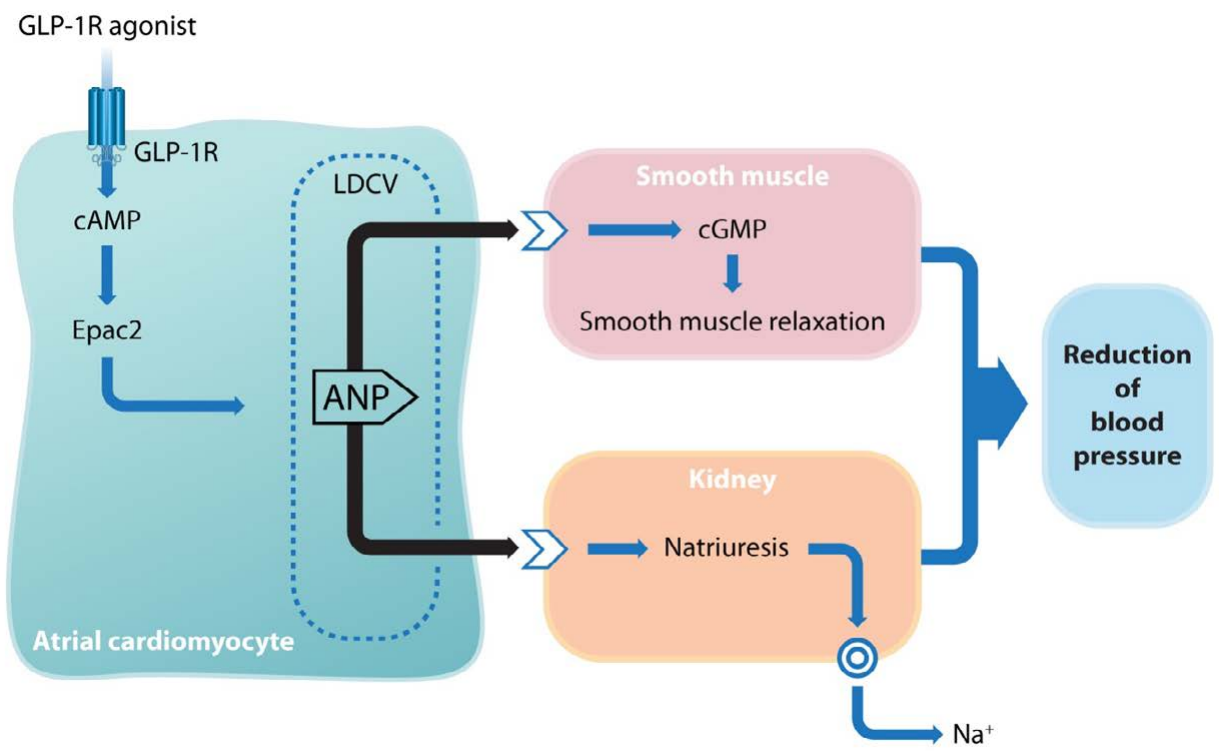

Figure 2: Mechanism of action for GLP-1 regulation of blood pressure. Reprinted with permission from Kim et al. Nat Med. 2013;19 (5):567-575 [41] 
Citation: Chilton RJ (2015) Potential Cardiovascular Effects of the Glucagon-like Peptide-1 Receptor Agonists. J Diabetes Metab 6: 483. doi:10.4172/2155-6156.1000483

Page 4 of 12

\begin{tabular}{|c|c|c|c|c|}
\hline Study & Design & Heart rate & SBP & DBP \\
\hline \multicolumn{5}{|c|}{ DURATION trials of exenatide } \\
\hline $\begin{array}{l}\text { Drucker } 2008 \\
\text { (DURATION-1) [43] }\end{array}$ & $\begin{array}{l}\text { 30-week study, monotherapy or } \\
\text { adjunct to oral agents }\end{array}$ & Not reported & $\begin{array}{l}\text { Exenatide QW: }-4.7 \mathrm{mmHg} \\
\text { Exenatide BID: }-3.4 \mathrm{mmHg}\end{array}$ & $\begin{array}{l}\text { Exenatide QW: }-1.7 \mathrm{mmHg} \\
\text { Exenatide BID: }-1.7 \mathrm{mmHg}\end{array}$ \\
\hline $\begin{array}{l}\text { Buse } 2010 \\
\text { (DURATION-1 } \\
\text { extension) [51] }\end{array}$ & $\begin{array}{l}\text { 22-week extension of } \\
\text { DURATION-1 study ( } 52 \text { weeks } \\
\text { total), monotherapy or adjunct to } \\
\text { oral agents; after initial } 30 \text { weeks, } \\
\text { switch from exenatide BID to QW } \\
\text { or continued exenatide QW }\end{array}$ & Not reported & $\begin{array}{l}\text { Exenatide } \mathrm{QW}:-6.2 \mathrm{mmHg} \\
(\mathrm{p}<0.05 \mathrm{vs} . \text { baseline }) \\
\text { Exenatide BID } \rightarrow \mathrm{QW}: \\
-3.8 \mathrm{mmHg}\end{array}$ & $\begin{array}{l}\text { Exenatide QW: }-2.8 \mathrm{mmHg} \\
\text { Exenatide BID } \rightarrow \text { QW: } \\
-1.8 \mathrm{mmHg}\end{array}$ \\
\hline $\begin{array}{l}\text { MacConell } 2013 \\
\text { (DURATION-1 } \\
\text { extension) [52] }\end{array}$ & $\begin{array}{l}\text { Extension of DURATION-1 study } \\
\text { to } 3 \text { years (reported for completer } \\
\text { population); all patients receiving } \\
\text { exenatide QW after initial } 30 \\
\text { weeks }\end{array}$ & Not reported & $-2.14 \mathrm{mmHg}$ & $-2.0 \mathrm{mmHg}(\mathrm{p}<0.05$ vs. baseline $)$ \\
\hline $\begin{array}{l}\text { Bergenstal } 2010 \\
\text { (DURATION-2) [44] }\end{array}$ & $\begin{array}{l}\text { 26-week study, adjunct to } \\
\text { metformin }\end{array}$ & Not reported & $\begin{array}{l}\text { Improvements in patients } \\
\text { receiving exenatide } Q W \text { and } \\
\text { pioglitazone (exenatide } Q W \\
p=0.0055 \text { vs. sitagliptin) }\end{array}$ & $\begin{array}{l}\text { Changes did not differ significantly } \\
\text { between groups }\end{array}$ \\
\hline $\begin{array}{l}\text { Diamant } 2010 \\
\text { (DURATION-3) [45] }\end{array}$ & $\begin{array}{l}\text { 26-week study, adjunct to oral } \\
\text { agents }\end{array}$ & $\begin{array}{l}\text { Exenatide } \mathrm{QW}:+4.0 \mathrm{bpm}(\mathrm{p}<0.05 \\
\text { vs. baseline) } \\
\text { Insulin glargine: } 0 \mathrm{bpm}\end{array}$ & $\begin{array}{l}\text { Exenatide } Q W:-3.0 \mathrm{mmHg} \\
(p<0.05 \text { vs baseline }) \\
\text { Insulin glargine: }-1.0 \mathrm{mmHg}\end{array}$ & $\begin{array}{l}\text { Exenatide QW: }-1.0 \mathrm{mmHg} \\
\text { Insulin glargine: }-1.0 \mathrm{mmHg}\end{array}$ \\
\hline $\begin{array}{l}\text { Diamant } 2012 \\
\text { (DURATION-3 } \\
\text { extension) [49] }\end{array}$ & $\begin{array}{l}\text { 84-week study, adjunct to oral } \\
\text { agents }\end{array}$ & $\begin{array}{l}\text { Exenatide } Q W:+1.97 \mathrm{bpm}(\mathrm{p}<0.05 \\
\text { vs. baseline }) \\
\text { Insulin glargine: } \\
-0.79 \mathrm{bpm}\end{array}$ & $\begin{array}{l}\text { Exenatide } \mathrm{QW}:-4.2 \mathrm{mmHg} \\
(\mathrm{p}<0.05 \text { vs. baseline }) \\
\text { Insulin glargine: }-0.8 \mathrm{mmHg}\end{array}$ & $\begin{array}{l}\text { Exenatide } Q W:-1.5 \mathrm{mmHg} \text { ( } p<0.05 \text { vs } \\
\text { baseline) } \\
\text { Insulin glargine: }-1.4 \mathrm{mmHg}(\mathrm{p}<0.05 \text { vs. } \\
\text { baseline) }\end{array}$ \\
\hline $\begin{array}{l}\text { Diamant } 2014 \\
\text { (DURATION-3 } \\
\text { extension) [50] }\end{array}$ & $\begin{array}{l}\text { 156-week study, adjunct to oral } \\
\text { agents }\end{array}$ & $\begin{array}{l}\text { Exenatide } Q W:+2 \mathrm{bpm} \\
\text { Insulin glargine: }-1 \mathrm{bpm}\end{array}$ & $\begin{array}{l}\text { Exenatide QW: }-2 \mathrm{mmHg} \\
\text { Insulin glargine: }+2 \mathrm{mmHg}\end{array}$ & $\begin{array}{l}\text { Exenatide } \mathrm{QW}:-2 \mathrm{mmHg} \\
\text { Insulin glargine: }-2 \mathrm{mmHg}\end{array}$ \\
\hline $\begin{array}{l}\text { Russell-Jones } 2012 \\
\text { (DURATION-4) [48] }\end{array}$ & 26-week study, monotherapy & $\begin{array}{l}\text { Exenatide QW: }+1.5 \mathrm{bpm} \\
\text { Metformin: }+0.3 \mathrm{bpm} \\
\text { Sitaglipin: }+0.5 \mathrm{bpm} \\
\text { Pioglitazone: }-1.7 \mathrm{bpm}\end{array}$ & $\begin{array}{l}\text { Exenatide QW: }-1.3 \mathrm{mmHg} \\
\text { Pioglitazone: }-1.7 \mathrm{mmHg} \\
\text { Sitagliptin: }-1.8 \mathrm{mmHg}\end{array}$ & Pioglitazone: $-2.5 \mathrm{mmHg}$ \\
\hline $\begin{array}{l}\text { Blevins } 2011 \\
\text { (DURATION-5) [47] }\end{array}$ & $\begin{array}{l}\text { 24-week study, monotherapy or } \\
\text { adjunct to oral agents }\end{array}$ & $\begin{array}{l}\text { Exenatide QW: }+4.1 \mathrm{bpm}(\mathrm{p}<0.05 \\
\text { vs. baseline) } \\
\text { Exenatide BID: }+2.1 \mathrm{bpm}(\mathrm{p}<0.05 \\
\text { vs. baseline })\end{array}$ & $\begin{array}{l}\text { Exenatide } \mathrm{QW}:-2.9 \mathrm{mmHg} \\
\text { ( }<<0.05 \text { vs. baseline) } \\
\text { Exenatide BID: }-1.2 \mathrm{mmHg}\end{array}$ & $\begin{array}{l}\text { Exenatide QW: }+0.2 \mathrm{mmHg} \\
\text { Exenatide BID: }-0.1 \mathrm{mmHg}\end{array}$ \\
\hline $\begin{array}{l}\text { Buse } 2013 \\
\text { (DURATION-6) [46] }\end{array}$ & $\begin{array}{l}\text { 26-week study, adjunct to oral } \\
\text { agents }\end{array}$ & Not reported & $\begin{array}{l}\text { Exenatide } Q W:-2.48 \mathrm{mmHg} \\
(p<0.05 \text { vs. baseline }) \\
\text { Liraglutide QD: }-3.45 \mathrm{mmHg} \\
(p<0.05 \text { vs. baseline })\end{array}$ & $\begin{array}{l}\text { Exenatide QW: }-0.49 \mathrm{mmHg} \\
\text { Liraglutide QD: }-0.51 \mathrm{mmHg}\end{array}$ \\
\hline \multicolumn{5}{|c|}{ LEAD studies of liraglutide } \\
\hline $\begin{array}{l}\text { Marre } 2009 \text { (LEAD-1 } \\
\text { SU) [58] }\end{array}$ & $\begin{array}{l}\text { 26-week study, adjunct to } \\
\text { sulfonylurea }\end{array}$ & $\begin{array}{l}\text { Liraglutide ( } 3 \text { doses): }+2-4 \text { bpm (all } \\
3 \text { doses } p \leq 0.002 \text { vs. placebo; } 1.8 \\
\text { or } 1.2 \text { mg } p<0.01 \text { vs rosiglitazone) } \\
\text { Rosiglitazone: }+1 \text { bpm } \\
\text { Placebo: } \\
-1 \text { bpm }\end{array}$ & $\begin{array}{l}\text { Liraglutide ( } 2 \text { doses): } \\
-2.6 \text { to }-2.8 \mathrm{mmHg} \\
\text { Rosiglitazone/placebo: }-0.9 \text { to } \\
-2.3 \mathrm{mmHg}\end{array}$ & Across the 4 arms: -0.7 to $-1.4 \mathrm{mmHg}$ \\
\hline $\begin{array}{l}\text { Nauck } 2009 \text { (LEAD- } \\
\text { 2) [59] }\end{array}$ & $\begin{array}{l}\text { 26-week study, adjunct to } \\
\text { metformin }\end{array}$ & $\begin{array}{l}\text { Liraglutide ( } 3 \text { doses }):+2-3 \text { bpm } \\
(0.6 \mathrm{mg} p=0.012,1.2 \mathrm{mg} p=0.024 \\
\text { vs. glimepiride }) \\
\text { Glimepiride: }+1 \mathrm{bpm} \\
\text { Placebo: }+1 \mathrm{bpm}\end{array}$ & $\begin{array}{l}\text { Liraglutide } 0.6 \mathrm{mg}:-0.6 \mathrm{mmHg} \\
\text { Liraglutide } 1.2 \mathrm{mg}:-2.8 \mathrm{mmHg} \\
\text { ( } p=0.0128 \text { vs. glimepiride) } \\
\text { Liraglutide } 1.8 \mathrm{mg}:-2.3 \mathrm{mmHg} \\
\text { ( } p=0.0467 \text { vs. glimepiride) } \\
\text { Glimepiride: }+0.4 \mathrm{mmHg} \\
\text { Placebo: }-1.8 \mathrm{mmHg}\end{array}$ & $\begin{array}{l}\text { Specific data not reported (qualitatively, } \\
\text { there was no apparent change in DBP } \\
\text { from baseline in any group) }\end{array}$ \\
\hline $\begin{array}{l}\text { Garber } 2009 \text { (LEAD-3 } \\
\text { [Mono]) [57] }\end{array}$ & 52-week study, monotherapy & $\begin{array}{l}\text { Liraglutide } 1.2 \mathrm{mg}:+3.2 \mathrm{bpm} \\
(\mathrm{p}=0.0027 \mathrm{vs} . \text { glimepiride }) \\
\text { Liraglutide } 1.8 \mathrm{mg}:+1.6 \mathrm{bpm} \\
\text { Glimepiride: }+0.4 \mathrm{bpm}\end{array}$ & $\begin{array}{l}\text { Liraglutide } 1.2 \mathrm{mg}:-2.1 \mathrm{mmHg} \\
\text { Liraglutide } 1.8 \mathrm{mg}:-3.6 \mathrm{mmHg} \\
\text { ( } p<0.0118 \mathrm{vs} . \text { glimepiride) } \\
\text { Glimepiride: }-0.7 \mathrm{mmHg}\end{array}$ & $\begin{array}{l}\text { Specific data not reported (qualitatively, } \\
\text { all groups had slight, nonsignificant } \\
\text { DBP reductions) }\end{array}$ \\
\hline $\begin{array}{l}\text { Garber } 2011 \text { (LEAD-3 } \\
\text { [Mono]) [56] }\end{array}$ & $\begin{array}{l}\text { 1-year extension of LEAD-3, } \\
\text { monotherapy }\end{array}$ & $\begin{array}{l}\text { Liraglutide } 1.2 \mathrm{mg}:+2.04 \mathrm{bpm} \\
\text { Liraglutide } 1.8 \mathrm{mg}:+0.92 \mathrm{bpm} \\
\text { Glimepiride: }+0.67 \mathrm{bpm}\end{array}$ & $\begin{array}{l}\text { Liraglutide } 1.2 \mathrm{mg}: \\
-1.35 \mathrm{mmHg} \\
\text { Liraglutide } 1.8 \mathrm{mg}: \\
-2.37 \mathrm{mmHg} \\
\text { Glimepiride } 8 \mathrm{mg}: \\
-0.49 \mathrm{mmHg}\end{array}$ & $\begin{array}{l}\text { Liraglutide } 1.2 \mathrm{mg}:-0.58 \mathrm{mmHg} \\
\text { Liraglutide } 1.8 \mathrm{mg}:-0.81 \mathrm{mmHg} \\
\text { Glimepiride } 8 \mathrm{mg}:-0.44 \mathrm{mmHg}\end{array}$ \\
\hline $\begin{array}{l}\text { Russell-Jones } 2009 \\
\text { (LEAD-5 [met+SU]) } \\
\text { [60] }\end{array}$ & $\begin{array}{l}\text { 26-week study, adjunct metformin } \\
\text { and glimepiride }\end{array}$ & $\begin{array}{l}\text { Liraglutide } 1.8 \mathrm{mg}:+2.62 \mathrm{bpm} \\
\text { ( } p=0.0006 \text { vs. insulin glargine) } \\
\text { Insulin glargine: }+0.08 \mathrm{bpm} \\
\text { Placebo: }+0.93 \mathrm{bpm}\end{array}$ & $\begin{array}{l}\text { Liraglutide } 1.8 \mathrm{mg}:-4.0 \mathrm{mmHg} \\
(p=0.0001 \mathrm{vs} \text {. insulin glargine }) \\
\text { Insulin glargine: }+0.54 \mathrm{mmHg} \\
\text { Placebo: }-1.4 \mathrm{mmHg}\end{array}$ & $\begin{array}{l}\text { Specific data not reported; no } \\
\text { significant difference in reductions } \\
\text { between treatment groups }\end{array}$ \\
\hline
\end{tabular}




\begin{tabular}{|c|c|c|c|c|}
\hline $\begin{array}{l}\text { Buse } 2009 \text { (LEAD-6) } \\
\text { [55] }\end{array}$ & $\begin{array}{l}\text { 26-week study, adjunct to oral } \\
\text { agents }\end{array}$ & $\begin{array}{l}\text { Liraglutide: }+3.28 \mathrm{bpm}(\mathrm{p}=0.0012 \\
\text { vs. exenatide) } \\
\text { Exenatide: }+0.69 \mathrm{bpm}\end{array}$ & $\begin{array}{l}\text { Liraglutide: }-2.51 \mathrm{mmHg} \\
\text { Exenatide: }-2.00 \mathrm{mmHg}\end{array}$ & $\begin{array}{l}\text { Liraglutide: }-1.05 \mathrm{mmHg} \\
\text { Exenatide: }-1.98 \mathrm{mmHg}\end{array}$ \\
\hline $\begin{array}{l}\text { Buse } 2010 \text { (LEAD-6) } \\
\text { [54] }\end{array}$ & $\begin{array}{l}\text { 14-week extension of LEAD- } 6 \text {, } \\
\text { switch from exenatide BID to } \\
\text { liraglutide } 1.8 \mathrm{mg} \text { QD or continued } \\
\text { liraglutide }\end{array}$ & Not reported & $\begin{array}{l}\text { Exenatide } \rightarrow \text { Liraglutide: }-3.8 \\
\mathrm{mmHg}(p<0.0001 \text { vs. Week } \\
26) \\
\text { Liraglutide: }-2.2 \mathrm{mmHg} \\
(p=0.0128 \text { vs. Week } 26)\end{array}$ & $\begin{array}{l}\text { Specific data not reported; no } \\
\text { significant changes observed in either } \\
\text { treatment group }\end{array}$ \\
\hline
\end{tabular}

BID: twice daily; bpm: beats per minute; DBP: diastolic blood pressure; DURATION: Diabetes therapy Utilization: Researching changes in A1c, weight and other factors Through Intervention with exenatide ONce weekly; LEAD: Liraglutide Effect and Action in Diabetes; QD: once daily; QW: once weekly; SBP: systolic blood pressure.

Table 1: Blood Pressure and Heart Rate Data from DURATION Trials of Exenatide and LEAD Trials of Liraglutide.

ranging from -1.3 to $-6.2 \mathrm{mmHg}$ in the DURATION trials of exenatide and from -0.6 to $-4.0 \mathrm{mmHg}$ in the LEAD trials of liraglutide. DBP reductions have also been observed, but these have been smaller and typically consistent with the observed reductions in the comparator groups; changes range from +0.2 to $-2.8 \mathrm{mmHg}$ with exenatide QW and from -0.6 to $-1.1 \mathrm{mmHg}$ with liraglutide. Other randomized studies of exenatide twice daily and once weekly [61-65] have yielded similar findings, with significant SBP reductions ranging from -3 to $-9 \mathrm{mmHg}$ and smaller (and significant in some but not all cases) DBP reductions of -0.4 to $-3 \mathrm{mmHg}$. In a randomized comparison of liraglutide versus sitagliptin, SBP/DBP changes were $-0.55 /-0.71$ $\mathrm{mmHg}$ with liraglutide $1.2 \mathrm{mg}$ and $-0.72 /+0.07 \mathrm{mmHg}$ with liraglutide $1.8 \mathrm{mg}$ after 26 weeks and $-0.37 /-0.53 \mathrm{mmHg}$ and $-2.55 /-0.87 \mathrm{mmHg}$, respectively, after 1 year; these changes did not represent significant benefits over the comparator sitagliptin $[66,67]$. Similar 52-week SBP reductions were seen for dulaglutide once weekly in the Assessment of Weekly AdministRation of LY2189265 (dulaglutide) in Diabetes (AWARD)-3 study (dulaglutide $1.5 \mathrm{mg},-0.1 \mathrm{mmHg}$; dulaglutide $0.75 \mathrm{mg},-2.7 \mathrm{mmHg}$; metformin, $-1.0 \mathrm{mmHg}$ ) [68] and the AWARD-5 trial (dulaglutide $1.5 \mathrm{mg},-0.8 \mathrm{mmHg}$; dulaglutide $0.75 \mathrm{mg},-0.5$ mmHg; sitagliptin, $-0.5 \mathrm{mmHg}$ ) [69]. The AWARD-1 trial showed no benefit in terms of 52-week SBP and DBP results for dulaglutide once weekly [70]. The AWARD-6 open-label non-inferiority study showed that once-weekly dulaglutide and once-daily liraglutide had similar reductions in SBP/DBP of $-3.36 /-0.22 \mathrm{mmHg}$ and $-2.82 /-0.31 \mathrm{mmHg}$, respectively, over 26 weeks [71].

Albiglutide once weekly added to background metformin was associated with reductions in SBP and DBP $(-1.0 \mathrm{mmHg}$ and -0.7 mmHg, respectively) in the HARMONY 3 study, with small increases observed in the placebo, sitagliptin, and glimepiride arms [72]. In HARMONY 7, which evaluated albiglutide once weekly versus liraglutide once daily in patients with inadequate control from oral anti-glycemic agents, SBP and DBP changes did not exceed $1 \mathrm{mmHg}$ in either treatment group [73]. In the 1-year HARMONY-4 study, patients with type 2 diabetes uncontrolled on metformin were randomized to albiglutide $30 \mathrm{mg}$ once weekly or insulin glargine [74]. Mean SBP decreased in the albiglutide group $(-1.4 \mathrm{mmHg})$ and increased slightly in the insulin group $(0.3 \mathrm{mmHg})$ and DBP decreased slightly in both groups $(-0.8 \mathrm{mmHg}$ and $-1.8 \mathrm{mmHg}$, respectively) [74].

Heart rate data were reported for some of the DURATION [4750] studies of exenatide once weekly and LEAD [56-58,60] studies of liraglutide, which revealed numerical increases in heart rate versus some of the comparator agents (Table 1). In a randomized comparison against sitagliptin, at 26 weeks both liraglutide $1.2 \mathrm{mg}$ and $1.8 \mathrm{mg}$ were associated with significant mean increases from baseline of 2.32 beats per minute (bpm; $\mathrm{p}=0.0002)$ and $3.94 \mathrm{bpm}(\mathrm{p}<0.0001)$, respectively, compared with the $-0.64 \mathrm{bpm}$ reduction in the sitagliptin group [66]. In AWARD-5, heart rate increases at 52 weeks were significantly higher
( $\mathrm{p}<0.0001)$ with dulaglutide $1.5 \mathrm{mg}(2.4 \mathrm{bpm})$ and with dulaglutide $0.75 \mathrm{mg}(2.1 \mathrm{bpm})$ than the $-0.3 \mathrm{bpm}$ reduction with sitagliptin [69]. In AWARD-1 and AWARD-3, heart rate increases ranged from 2.1 to $2.8 \mathrm{bpm}$ after 26 weeks of treatment across dulaglutide doses and were lower after 52 weeks of treatment (1.6 to $1.8 \mathrm{bpm}$ ); increases of $1.2 \mathrm{bpm}$ for once-weekly exenatide (AWARD-1) and $1.1 \mathrm{bpm}$ for metformin (AWARD-3) were observed after 52 weeks $[68,70]$. In AWARD-6, heart rate increases of $2.37 \mathrm{bpm}$ and $3.12 \mathrm{bpm}$ were observed for dulaglutide and liraglutide, respectively, with no significant difference between groups [71]. In a Japanese 12-week phase 2 dose-response study, small, but significant increases $(\mathrm{p}<0.005)$ in heart rate were observed with dulaglutide $0.25 \mathrm{mg}(+1.4 \mathrm{bpm}), 0.5 \mathrm{mg}(+1.56 \mathrm{bpm})$, and $0.75 \mathrm{mg}(+1.32 \mathrm{bpm})$ versus a decrease with placebo $(-3.44 \mathrm{bpm})$, but increases were not dose-dependent [75].

In HARMONY 3 and HARMONY 7, and HARMONY 4, heart rate increased by approximately $1 \mathrm{bpm}$ with albiglutide, compared with 2 bpm and $3 \mathrm{bpm}$ increases with placebo (HARMONY 3; 104 weeks) and liraglutide (HARMONY 7; 32 weeks), respectively [72,73], and no increase with insulin glargine (HARMONY 4; 52 weeks)[74]. Both GetGoal-X and GetGoal-S trials showed that heart rate changes were limited to increases or reductions of $0.1 \mathrm{bpm}$ for lixisenatide as well as for the respective comparators exenatide twice daily and placebo [76,77]. In GetGoal-M-Asia, heart rate increased by $0.7 \mathrm{bpm}$ with lixisenatide, but remained unchanged with placebo [78].

Data showing effects on BP also are available from several retrospective/post hoc combined analyses of clinical trials. In a post hoc analysis of BP-lowering effects from 6 trials of once-weekly or twicedaily exenatide versus placebo or insulin, the 6-month pooled data showed that exenatide recipients achieved SBP reductions that were significantly greater than those observed with placebo (least squares [LS] mean -2.2 vs. $+0.6 \mathrm{mmHg}$; $=0.0002$ ) or insulin (LS mean -4.5 vs. $-0.9 \mathrm{mmHg} ; \mathrm{p}<0.0001$ ) [79]. No significant differences were observed with respect to DBP reductions from baseline, which for exenatide were $-0.7 \mathrm{mmHg}$ and $-1.6 \mathrm{mmHg}$ in the comparisons against placebo and insulin, respectively (corresponding reductions for placebo and exenatide were -0.2 and $-0.8 \mathrm{mmHg}$, respectively). Exenatideassociated SBP reductions were most pronounced among patients with elevated SBP at baseline. Within this same report, analysis of treatment effects by baseline BP showed that the largest between-group differences between exenatide and the comparators were in patients with baseline SBP $\geq 150 \mathrm{mmHg}$. More recently, in a retrospective analysis of BP and Low-Density Lipoprotein (LDL) cholesterol from three trials of exenatide once weekly versus oral glucose-lowering medications or insulin glargine, the proportions of patients reaching goal SBP $<130 \mathrm{mmHg}$ were highest among the exenatide recipients [80]. Most notably, in the DURATION-2 trial, $56.9 \%$ of exenatide recipients achieved goal SBP versus $34.8 \%$ and $39.1 \%$ of sitagliptin and pioglitazone recipients, respectively. The differences in the proportions 
Citation: Chilton RJ (2015) Potential Cardiovascular Effects of the Glucagon-like Peptide-1 Receptor Agonists. J Diabetes Metab 6: 483. doi:10.4172/2155-6156.1000483

of patients attaining a SBP goal were smaller in the other 2 trials, with a rate of $25.3 \%$ for exenatide versus $21.3 \%$ with insulin glargine in DURATION-3 and a rate of $39.7 \%$ with exenatide versus $25.0 \%, 31.2 \%$, and $32.2 \%$ with metformin, sitagliptin, and pioglitazone, respectively. Recently, an analysis of 6 randomized controlled trials of liraglutide was conducted, showing that SBP reductions achieved with liraglutide after 26 weeks were significantly greater than those observed with placebo (mean $-2.7 \mathrm{mmHg}$ for $1.2 \mathrm{mg}$ and $-2.9 \mathrm{mmHg}$ for $1.8 \mathrm{mg}$ vs. $-0.5 \mathrm{mmHg} ; \mathrm{p}=0.0029$ and $\mathrm{p}=0.0004$, respectively) [81]. Reductions in SBP also were significantly greater for liraglutide (either dose) versus glimepiride and specifically for the 1.8 -mg dose versus insulin glargine or rosiglitazone; only liraglutide $1.8 \mathrm{mg}$ was compared with exenatide twice daily, for which there were no differences in SBP reduction. At week 26, liraglutide recipients had heart rate values that were significantly higher compared with baseline and those in the placebo group, with placebo-adjusted changes of $2.33 \mathrm{bpm}$ for liraglutide 1.2 $\mathrm{mg}$ and $2.57 \mathrm{bpm}$ for liraglutide $1.8 \mathrm{mg}$ (both $\mathrm{p}<0.0001$ ).

Data from a post hoc analysis of heart rate and Major Adverse Cardiac Events (MACE) from 11 studies comparing exenatide once weekly with an active comparator (ie, exenatide twice daily, insulin, liraglutide, metformin, pioglitazone, sitagliptin) or placebo demonstrated that heart rate variability was observed for all treatments over time; mean increases in heart rate were small and transient, and increases were not prevalent after 10 weeks [82]. In addition, most of those who experienced an increased heart rate had among the lowest baseline heart rates, such that heart rate increases were negatively correlated with baseline heart rate. No associations were observed between MACE and small mean increased heart rate, although further study is needed.

\section{Lipids}

Lipid data derived from the DURATION studies of exenatide once weekly support improvements in several parameters [43-46,83]. In a post hoc analysis of DURATION-1, a 30-week course of exenatide once weekly was associated with significant reductions from baseline in triglycerides, apolipoprotein B $(-0.036 \%)$, apolipoprotein B-to-A1 ratio $(-3.1 \%)$, LDL4, and very low-density lipoprotein (VLDL) (all $\mathrm{p}<0.05$; Figure 3 ), in conjunction with a significant increase in highdensity lipoprotein 2 (HDL2) $(\mathrm{p}<0.05$; Figure 3$)$. With exenatide twice daily, significant reductions were limited to triglycerides and VLDL ( $p<0.05$; Figure 3) [83]. In DURATION-2, significant improvements in HDL from baseline were observed, albeit significantly lower than that observed with pioglitazone [44]. In DURATION-5, significant reductions were observed in mean fasting total cholesterol and LDL with exenatide once weekly; however, no significant changes in lipid parameters were observed with exenatide twice daily [47]. In DURATION-6, changes in the lipid profile were more pronounced with liraglutide versus exenatide once weekly with respect to total cholesterol, non-HDL, and LDL, with a rise in HDL of $+0.02 \mathrm{mmol} / \mathrm{L}$ in both treatment groups [46]. In the LEAD-6 study, liraglutide and exenatide twice daily were associated with similar reductions in total cholesterol and LDL and increases in HDL; however, changes in VLDL, triglycerides, and free fatty acids significantly favored the liraglutide group [55]. In addition to the DURATION and LEAD studies, data derived from a number of other randomized studies of exenatide once weekly or twice daily $[61,62,64,84,85]$, liraglutide $[66,67,86]$, and dulaglutide $[69,70]$ lend further support to the ability of these agents to improve some lipid profile components among patients with type 2 diabetes. Meaningful improvements in lipid parameters
A.

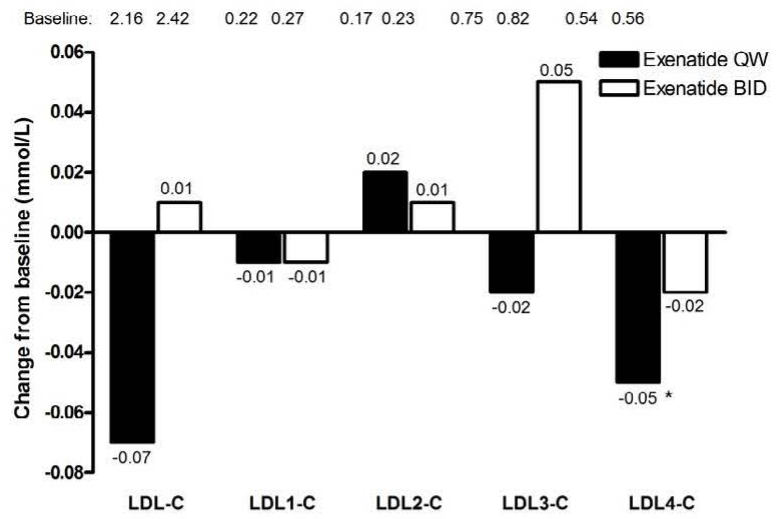

B.

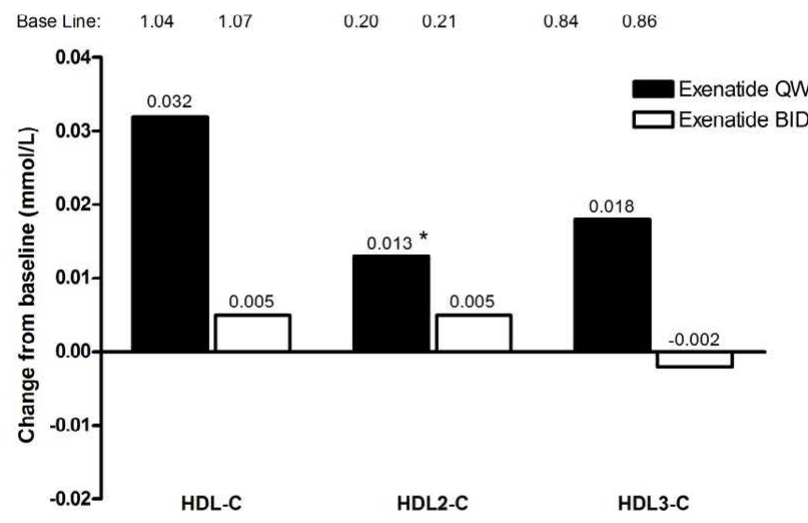

c.

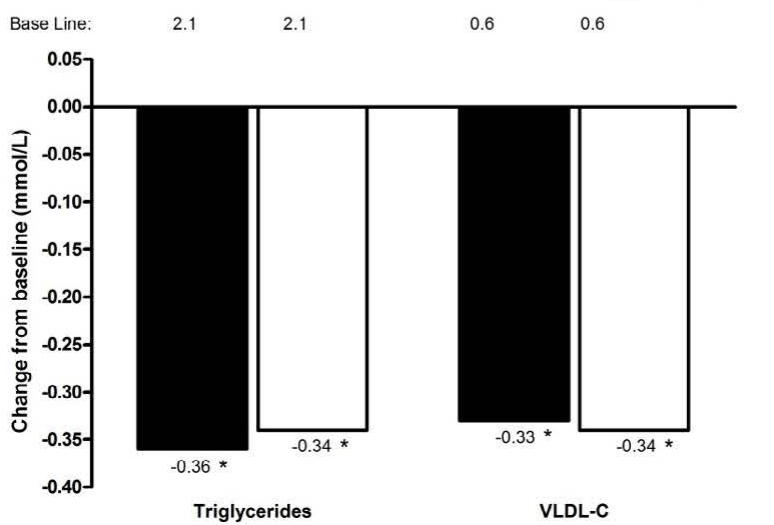

Figure 3: Effects of exenatide on lipoproteins in the total analysis cohort with an overall normal lipid profile at baseline. Week 30 change data are independent of glycemic improvement and weight loss. (A) LDL-C and its subclasses. (B) HDL-C and its subclasses. (C) Triglycerides and VLDL-C. Adjusted mean. Notes: ${ }^{*}$ Week 30 change from baseline $p<0.05$. Once weekly, $n=106$, twice daily, $n=105$. Abbreviations: BID: twice daily; LDL-C: low-density lipoprotein cholesterol; VLDL-C: very low-density lipoprotein cholesterol; HDL-C: high-density lipoprotein cholesterol; QW: once weekly. Adapted with permission from Chiquette et al. Vasc Health Risk Manag. 2012;8:621-629 [83]. 
were not observed with albiglutide in HARMONY 3 or HARMONY 7 [72,73], or lixisenatide in GetGoal-S [76]. In the HARMONY-4 study, similar small reductions in LDL-cholesterol, total cholesterol, and triglycerides, and a small increase in HDL-cholesterol were observed with albiglutide added to insulin and in the standard insulin therapy group [74]. In the aforementioned retrospective analysis of three trials of exenatide once weekly versus oral glucose-lowering medications or insulin glargine, exenatide was associated with a somewhat increased propensity for achieving an LDL cholesterol level $<100 \mathrm{mg} /$ dL compared with sitagliptin and pioglitazone (20.2\% vs. $13.8 \%$ and $13.0 \%$, respectively, in DURATION-4; $29.8 \%$ vs. $21.6 \%$ and $19.4 \%$, respectively, in DURATION-2) but not when exenatide was compared with metformin $(20.2 \%$ vs. $23.1 \%$ in DURATION-4) [80]. In the Japanese dose-response study, two patients receiving dulaglutide 0.25 $\mathrm{mg} /$ week had elevated triglycerides [75].

\section{Corrected QT interval effects}

The effects of GLP-1RAs on the corrected QT interval have been examined in healthy subjects in randomized, placebo-controlled studies, which identified no evidence of clinically relevant prolongation for subjects receiving daily (subcutaneously or via infusion to reach steady state) exenatide $[87,88]$, liraglutide [89], or albiglutide [90].

\section{Reducing damage after MI}

Exenatide (given via infusion, dosed to a prespecified target plasma concentration) was recently shown, for the first time, to increase myocardial salvage in patients with ST-segment-elevation MI (STEMI) undergoing primary percutaneous coronary intervention (pPCI) [91]. In this study of 172 patients in this setting, there were significant differences favoring exenatide versus placebo with respect to the primary end point of acute phase salvage index ( 0.71 vs. 0.62 ; $\mathrm{p}=0.003)$ as well as Day 90 final infarct size/myocardial area at risk ratio ( 0.30 vs. $0.39 \mathrm{~g} ; \mathrm{p}=0.003)$. Results of another randomized placebocontrolled trial of intravenous exenatide, administered prior to PCI, in 210 patients presenting with ST-segment elevation have since been published [92]. The results described the association between hyperglycemia and infarct size (related to myocardial area at risk, but not myocardial salvage), as well as the ability of intravenous exenatide to increase the salvage index, which was numerically greater in the setting of normoglycemia ( 0.68 vs. $0.62 ; \mathrm{p}=0.08)$ and significant for hyperglycemia ( 0.73 vs. $0.64 ; \mathrm{p}=0.017$ ). Also recently, in a smaller study of 58 patients, adjunctive exenatide therapy (five subcutaneous doses over 3 days, with an initial bolus dose with the first subcutaneous dose (given before the onset of reperfusion)) with pPCI was shown to reduce infarct size while also improving subclinical LV function in patients with STEMI [93].

\section{Circulating biomarker data}

In the DURATION-3 trial of exenatide once weekly versus insulin glargine, a significant reduction from baseline in high-sensitivity C-reactive protein (hsCRP) was observed with exenatide $(-2.0 \mathrm{mg} / \mathrm{L}$; $\mathrm{p}<0.05)$ but not insulin glargine $(-0.8 \mathrm{mg} / \mathrm{L})$, for a mean treatment difference of -1.2 ( $95 \%$ confidence interval (CI), -2.8 to 0.3 ) [45]. Subsequently, in DURATION-6, hsCRP was reduced by $-2.19 \mathrm{nmol} / \mathrm{L}$ in patients treated with exenatide once weekly versus a $0.29 \mathrm{nmol} / \mathrm{L}$ increase in patients treated with liraglutide, for a LS mean treatment difference of -2.48 ( $95 \%$ CI, -14.83 to 9.43) [46]. Conversely, reduction in B-type (brain) natriuretic peptide (BNP) was more pronounced with liraglutide versus exenatide once weekly $(-7.32$ vs $-4.45 \mathrm{ng} / \mathrm{L}$; LS mean treatment difference of $2.87 ; 95 \% \mathrm{CI},-0.76$ to 6.51 ). In the
DURATION-2 trial of exenatide once weekly versus sitagliptin and pioglitazone, treatment with exenatide once weekly was associated with significant improvements in BNP, albumin to creatinine ratio, hsCRP, and adiponectin; BNP was improved significantly more than sitagliptin or pioglitazone [44]. Biomarker data from several other randomized trials of exenatide twice daily $[94,95]$ and liraglutide $[86,96]$ collectively support favorable effects on hsCRP and/or BNP. The most detailed report of cardiovascular risk biomarker data is based on a randomized trial in which exenatide twice daily was as effective as insulin glargine in improving glycemic control [94,97]. After 1 year of treatment, exenatide was shown to not only reduce total and trunk fat mass, body weight, and waist circumference, but also improve circulating levels of hsCRP, total adiponectin, and leptin [94]. Moreover, changes in these circulating biomarkers appeared to be independent of the observed reductions in fat mass.

\section{Noteworthy cardiovascular adverse events}

The most common adverse events reported in randomized studies of exenatide once weekly or twice daily or liraglutide were gastrointestinal, although cardiovascular events were also observed, as expected in this patient population. In the DURATION-2 study of exenatide once weekly versus sitagliptin or pioglitazone, serious adverse events included coronary artery occlusion in two patients (both in the pioglitazone group), and cerebrovascular accident in 2 patients (one in the sitagliptin group and one in the pioglitazone group) [44]. No other noteworthy cardiovascular adverse events were reported in that study. In the analysis of patients who had switched from exenatide twice daily to liraglutide once daily in the LEAD-6 study of liraglutide, serious adverse events included single reports of cardiac failure and MI in those who switched and single reports of cerebral infarction, cerebrovascular accident, transient ischemic attack, acute coronary syndrome and coronary artery occlusion in those who continued liraglutide [54]. In AWARD-1, a recipient of dulaglutide $1.5 \mathrm{mg}$ had a fatal MI during the study [70]. In AWARD-6, one cardiovascular event of myocardial infarction occurred in a patient receiving liraglutide [71].

Results of a pooled analysis of 3,945 patients who participated across 12 randomized trials of exenatide twice daily versus placebo or insulin found no increased risk of MACE with exenatide and the possibility of an improved cardiovascular safety profile versus the comparator arms, with a primary MACE relative risk of 0.7 (95\% CI, $0.38-1.31)$ [98].

\section{Managing Modifiable Risk Factors to Reduce Cardiovascular Risk}

Managing multiple risk factors in patients with type 2 diabetes is an important treatment strategy to reduce the risk of cardiovascular, as well as microvascular, events. Results from the STENO-2 trial demonstrated that intensive, targeted, long-term (7.8 years), multifactorial intervention to manage modifiable risk factors (ie, hyperglycemia, hypertension, dyslipidemia, and microalbuminuria) in patients with type 2 diabetes and microalbuminuria significantly improved patient outcomes versus conventional therapy [4]. Compared with conventional therapy, patients in the intensive therapy group (stepwise diet/behavioral modification and pharmacologic therapy to achieve targets) had a significantly lower risk of cardiovascular disease (hazard ratio, 0.47; 95\% CI, 0.24-0.73), retinopathy (hazard ratio, 0.42 ; 95\% CI, 0.21-0.86), nephropathy (hazard ratio, 0.39; 95\% CI, 0.17-0.87), and autonomic neuropathy (hazard ratio, $0.37 ; 95 \% \mathrm{CI}$, 0.18-0.79). Patients from the STENO-2 study were then followed for 
5.5 years in a subsequent study to determine the effect of the intensive therapy regimen on mortality [99]. The follow-up results demonstrated that after a mean study time of 13.3 years the beneficial effects of the intensive versus the conventional regimen were sustained: overall mortality was significantly reduced (hazard ratio, 0.54 ; $95 \%$ CI, 0.32 $0.89 ; \mathrm{p}=0.02$ ) and there was a lower risk of death due to cardiovascular causes (hazard ratio, 0.43 ; 95\% CI, 0.19-0.94; $\mathrm{p}=0.04$ ) and a lower risk of cardiovascular events (hazard ratio, 0.41 ; 95\% CI, 0.25-0.67; $\mathrm{p}<0.001)$.

The importance of aggressive pharmacologic therapy also was demonstrated in the Clinical Outcomes Utilizing Revascularization and Aggressive Drug Evaluation (COURAGE) trial [100]. The primary objective of the COURAGE trial was to assess whether PCI plus lifestyle intervention/intensive pharmacologic therapy (ie, medical therapy) was superior to medical therapy without PCI in reducing the risk of cardiovascular events in patients with myocardial ischemia and significant coronary artery disease. Patients were followed for 2.5 to 7.0 years (median 4.6 years) and results showed that as in initial management strategy, PCI plus medical therapy did not significantly reduce the composite end point of death and non-fatal MI ( $\mathrm{p}=0.62)$; composite endpoint of death, $\mathrm{MI}$, and stroke ( $\mathrm{p}=0.62)$; or the end points hospitalization for acute coronary syndrome $(\mathrm{p}=0.56)$, death $(\mathrm{p}=0.38)$, total non-fatal MI ( $\mathrm{p}=0.33)$, or stroke $(\mathrm{p}=0.19)$ versus medical therapy alone. Data from COURAGE showed that lifestyle intervention with intensive medical therapy to achieve aggressive targets was safe and effective in mitigating clinical events. Although COURAGE was not designed to be a diabetes study, $34 \%$ of the patient population had diabetes.

\section{Anticipated Cardiovascular Data from Ongoing Phase 3 Trials}

A number of clinical investigations of exenatide, liraglutide, dulaglutide, and lixisenatide are in progress, for which forthcoming results will provide further insight into the potential of GLP-1RAs as cardioprotective agents (Table 2). In one trial (NCT01373216), a 72hour infusion of exenatide is being tested for its ability to improve glucose control and cardiac function among patients with type 2 diabetes, coronary atherosclerosis, and LV dysfunction who are undergoing coronary artery bypass grafting; primary outcomes are effects on cardiac function, including cardiac chamber dimensions, LV systolic function, LV diastolic function, and right ventricular systolic function. The Effect of additional treatment with EXenatide in patients with an Acute Myocardial Infarction (EXAMI) trial (NCT01254123) $[101,102]$ is a pilot study assessing the safety and efficacy of exenatide infusion compared with placebo in patients with an acute MI undergoing pPCI. The Exenatide Study of Cardiovascular Event Lowering (EXSCEL) trial (NCT01144338) is a placebo-controlled phase 4 trial examining exenatide once weekly for improving cardiovascular outcomes in patients with type 2 diabetes. The primary outcome is time to first confirmed cardiovascular event in the primary composite cardiovascular endpoint.

Liraglutide is being examined for improving cardiometabolic risk markers in patients with type 2 diabetes, with a primary outcome measure of change in carotid intima-media thickness (NCT01715428). The Liraglutide Effect and Action in Diabetes: Evaluation of cardiovascular outcome Results (LEADER) trial (NCT01179048) is a long-term (60 months) international study designed to determine the effect of liraglutide on cardiovascular events in patients with type 2 diabetes. The primary outcome is the time from randomization to the first occurrence of the composite cardiovascular outcome of cardiovascular death, non-fatal MI, or non-fatal stroke. Liraglutide is also being investigated in the ongoing 6-month randomized AddHope2 study (NCT01595789) in patients with newly diagnosed type 2 diabetes and coronary artery disease. The study will investigate the effect of adding liraglutide to metformin on glucose metabolic and cardiovascular end points including BP, heart rate, and left-ventricular ejection fraction (LVEF) over 12 weeks [103]. In the ongoing 24week randomized controlled LIVE study (effect of LIraglutide on left VEntricular function; NCT01472640), 240 patients with chronic heart failure (LVEF $\leq 45 \%$ ) with and without type 2 diabetes will be randomized to liraglutide $1.8 \mathrm{mg}$ once daily or placebo [104]. The primary end point will be the effect of liraglutide on left ventricular systolic function (change in LVEF assessed using three-dimensional contrast echocardiography) versus placebo. Secondary end points will include left ventricular diastolic function, functional capacity (6-minute walk test), BNP levels, BP, heart rate, weight loss, total body composition, ECG, and quality of life evaluation [104].

In the Researching Cardiovascular Events with a Weekly Incretin in Diabetes (REWIND) trial (NCT01394952), dulaglutide is being examined versus placebo to determine the time to first occurrence of cardiovascular death, nonfatal MI, or nonfatal stroke. Lixisenatide is being compared with placebo in patients with type 2 diabetes who recently experienced an acute coronary event in the Evaluation of Lixisenatide in acute coronary syndrome (ELIXA) trial (NCT01147250). The primary outcome is the time to first occurrence of the primary cardiovascular event (cardiovascular death, non-fatal MI, non-fatal stroke, hospitalization for unstable angina).

\section{Key Outstanding Questions and PrioritiesfFor Future Research}

Results of the prospective outcome trials of the GLP-1RAs described herein are awaited to determine the extent to which the findings are supportive of published research from preclinical series. Additionally, further basic research efforts are needed to more fully characterize the mechanisms by which the GLP-1RAs exert cardioprotective benefit, and also to determine if there are any noteworthy differences between individual agents in this regard. Moreover, additional studies will help to determine if the cardiovascular safety profile of GLP1RAs is appropriate for use in at-risk populations and define in which populations GLP1-RAs might improve cardiovascular outcomes.

\section{Summary}

The GLP-1RAs are providing the opportunity for concurrent glycemic control and reduction of specific cardiovascular risk factors, such as hypertension and hyperlipidemia, in patients with type 2 diabetes. Most of the available randomized clinical trial cardiovascular data are in support of BP- and lipid-lowering effects, but favorable findings are accumulating regarding protection from MI-induced damage and circulating improvements in levels of the cardiovascular biomarkers hsCRP and BNP. An association between increased heart rate and adverse events has not been observed. Data from ongoing phase 3 trials of exenatide, liraglutide, dulaglutide, and lixisenatide, and a phase 4 trial of exenatide are awaited, to more fully characterize the cardioprotective effects of the GLP-1RAs. The effects of GLP-1RAs on proteomics and microRNAs are undergoing extensive investigation to ascertain their effect on myocardial protection in patients with or without diabetes by improving prosurvival kinases. 
Citation: Chilton RJ (2015) Potential Cardiovascular Effects of the Glucagon-like Peptide-1 Receptor Agonists. J Diabetes Metab 6: 483. doi:10.4172/2155-6156.1000483

Page 9 of 12

\begin{tabular}{|c|c|c|c|c|}
\hline Study & Study arms & Population & Primary outcome & $\begin{array}{l}\text { Estimated study } \\
\text { completion }\end{array}$ \\
\hline NCT01373216 & $\begin{array}{l}\text { Exenatide vs. no } \\
\text { intervention }\end{array}$ & $\begin{array}{l}38 \text { patients with type } 2 \text { diabetes undergoing } \\
\text { elective aortocoronary bypass }\end{array}$ & $\begin{array}{l}\text { Cardiac function - echocardiographic } \\
\text { parameters }\end{array}$ & April 2014 \\
\hline $\begin{array}{l}\text { NCT01254123 } \\
\text { (EXAMI) }[101,102]\end{array}$ & Exenatide vs. placebo & $\begin{array}{l}40 \text { patients with first acute myocardial } \\
\text { infarction undergoing primary } \mathrm{PCl}\end{array}$ & Safety & Unknown \\
\hline $\begin{array}{l}\text { NCT01144338 } \\
(\text { EXSCEL) }\end{array}$ & Exenatide vs. placebo & 14,000 patients with type 2 diabetes & $\begin{array}{l}\text { Time to composite endpoint of cardiovascular } \\
\text { death, non-fatal myocardial infarction, or non- } \\
\text { fatal stroke }\end{array}$ & April 2018 \\
\hline NCT01715428 & Liraglutide & 300 patients with type 2 diabetes & Carotid intima-media thickness & December 2015 \\
\hline $\begin{array}{l}\text { NCT01179048 } \\
\text { (LEADER) }\end{array}$ & Liraglutide vs. placebo & 9,340 patients with type 2 diabetes & $\begin{array}{l}\text { Time to composite endpoint of cardiovascular } \\
\text { death, non-fatal myocardial infarction, or non- } \\
\text { fatal stroke }\end{array}$ & October 2015 \\
\hline $\begin{array}{l}\text { NCT01595789 } \\
\text { (AddHope2) [103] }\end{array}$ & Liraglutide vs. placebo & $\begin{array}{l}40 \text { patients with coronary artery disease } \\
\text { and newly diagnosed type } 2 \text { diabetes }\end{array}$ & $\begin{array}{l}\text { Beta-cell function and left ventricular ejection } \\
\text { fraction after } 12 \text { weeks }\end{array}$ & October 2015 \\
\hline $\begin{array}{l}\text { NCT01472640 (LIVE) } \\
\text { [104] }\end{array}$ & Liraglutide vs. placebo & $\begin{array}{l}240 \text { patients with chronic heart failure with } \\
\text { and without diabetes }\end{array}$ & Change in left ventricular function & December 2014 \\
\hline $\begin{array}{l}\text { NCT01394952 } \\
\text { (REWIND) }\end{array}$ & Dulaglutide vs. placebo & 9,622 patients with type 2 diabetes & $\begin{array}{l}\text { Time to first occurrence of cardiovascular } \\
\text { death, nonfatal myocardial infarction, or } \\
\text { nonfatal stroke }\end{array}$ & April 2019 \\
\hline $\begin{array}{l}\text { NCT01147250 } \\
(\text { ELIXA) }\end{array}$ & Lixisenatide vs. placebo & $\begin{array}{l}6,000 \text { patients with type } 2 \text { diabetes who } \\
\text { recently experienced an acute coronary } \\
\text { syndrome event }\end{array}$ & $\begin{array}{l}\text { Time to first occurrence of the primary } \\
\text { cardiovascular event }\end{array}$ & January 2015 \\
\hline
\end{tabular}

ELIXA, Evaluation of Lixasenatide in Acute Coronary Syndrome; EXAMI, Effect of Additional Treatment With EXenatide in Patients With an Acute Myocardial Infarction; EXSCEL, Exenatide Study of Cardiovascular Event Lowering; GLP-1: glucagon-like peptide-1; LEADER, Liraglutide Effect and Action in Diabetes: Evaluation of Cardiovascular Outcome Results; PCI, percutaneous coronary intervention; REWIND, Researching Cardiovascular Events with a Weekly Incretin in Diabetes

Table 2: Ongoing Trials of the Cardioprotective Effects of the GLP-1 Receptor Agonists.

\section{Acknowledgements}

Laurie Orloski, PharmD, RPh, on behalf of inScience Communications, Springer Healthcare, and Lisa M. Klumpp Callan, PhD, CMPP, and Mary Hines, BSc Hons, of inScience Communications, Springer Healthcare, provided medica writing support funded by AstraZeneca.

\section{References}

1. Nandish S, Wyatt J, Bailon O, Smith M, Oliveros R, et al. (2011) Implementing cardiovascular risk reduction in patients with cardiovascular disease and diabetes mellitus. Am J Cardiol 108: 42B-51B.

2. Stolar MW, Chilton RJ (2003) Type 2 diabetes, cardiovascular risk, and the link to insulin resistance. Clin Ther 25 Suppl B: B4-31.

3. Gaede P, Pedersen O (2004) Target intervention against multiple-risk markers to reduce cardiovascular disease in patients with type 2 diabetes. Ann Med 36: $355-366$

4. Gaede P, Vedel P, Larsen N, Jensen GV, Parving HH, et al. (2003) Multifactorial intervention and cardiovascular disease in patients with type 2 diabetes. $\mathrm{N}$ Engl J Med 348: 383-393.

5. Chiquette E, Chilton R (2002) Cardiovascular disease: much more aggressive in patients with type 2 diabetes. Curr Atheroscler Rep 4: 134-142.

6. Sanon S, Patel R, Eshelbrenner C, Sanon VP, Alhaddad M, et al. (2012) Acute coronary syndrome in patients with diabetes mellitus: perspectives of an interventional cardiologist. Am J Cardiol 110: 13B-23B.

7. Dailey G (2011) Early and intensive therapy for management of hyperglycemia and cardiovascular risk factors in patients with type 2 diabetes. Clin Ther 33 : 665-678.

8. Raccah D (2006) Importance of blood glucose management in the multifactoria approach of absolute cardiovascular risk in type 2 diabetes: the lessons from the Steno 2 study. Diabetes Metab 32 Spec No2: 2S48-51.

9. Duckworth W, Abraira C, Moritz T, Reda D, Emanuele N, et al. (2009) Glucose control and vascular complications in veterans with type 2 diabetes. $\mathrm{N} \mathrm{Engl} \mathrm{J}$ Med 360: 129-139.

10. ADVANCE Collaborative Group, Patel A, MacMahon S, Chalmers J, Neal B et al. (2008) Intensive blood glucose control and vascular outcomes in patients with type 2 diabetes. N Engl J Med 358: 2560-2572.

11. Ismail-Beigi F, Craven T, Banerji MA, Basile J, Calles J, et al. (2010) Effect of intensive treatment of hyperglycaemia on microvascular outcomes in type 2 diabetes: an analysis of the ACCORD randomised trial. Lancet 376: 419-430.
12. Tandon N, Ali MK, Narayan KM (2012) Pharmacologic prevention of microvascular and macrovascular complications in diabetes mellitus: implications of the results of recent clinical trials in type 2 diabetes. Am J Cardiovasc Drugs 12: 7-22.

13. Nissen SE, Wolski K (2007) Effect of rosiglitazone on the risk of myocardial infarction and death from cardiovascular causes. N Engl J Med 356: $2457-$ 2471.

14. Food and Drug Administration. Guidance for Industry: diabetes mellitus evaluating cardiovascular risk in new antidiabetic therapies to treat type 2 diabetes. Silver Spring, MD. 2008. www.fda.gov/downloads/Drugs/ GuidanceComplianceRegulatoryInformation/Guidances/ucm071627.pdf Accessed November 212014.

15. Chilton R, Wyatt J, Nandish S, Oliveros R, Lujan M (2011) Cardiovascular comorbidities of type 2 diabetes mellitus: defining the potential of glucagonlike peptide-1-based therapies. Am J Med 124: S35-53.

16. Hiatt WR, Kaul S, Smith RJ (2013) The cardiovascular safety of diabetes drugs-insights from the rosiglitazone experience. N Engl J Med 369: 1285-1287.

17. Okerson T, Chilton RJ (2012) The cardiovascular effects of GLP-1 receptor agonists. Cardiovasc Ther 30: e146-155.

18. Edwards CM (2004) GLP-1: target for a new class of antidiabetic agents? J R Soc Med 97: 270-274.

19. Drucker DJ (2001) Development of glucagon-like peptide-1-based pharmaceuticals as therapeutic agents for the treatment of diabetes. Curr Pharm Des 7: 1399-1412.

20. Madsbad S, Kielgast U, Asmar M, Deacon CF, Torekov SS, et al. (2011) An overview of once-weekly glucagon-like peptide-1 receptor agonists--available efficacy and safety data and perspectives for the future. Diabetes Obes Metab 13: 394-407.

21. Barragán JM, Rodríguez RE, Eng J, Blázquez E (1996) Interactions of exendin-(9-39) with the effects of glucagon-like peptide-1-(7-36) amide and of exendin-4 on arterial blood pressure and heart rate in rats. Regul Pept 67 : 63-68.

22. Hirata K, Kume S, Araki S, Sakaguchi M, Chin-Kanasaki M, et al. (2009) Exendin-4 has an anti-hypertensive effect in salt-sensitive mice model. Biochem Biophys Res Commun 380: 44-49.

23. Laugero KD, Stonehouse AH, Guss S, Landry J, Vu C, et al. (2009) Exenatide improves hypertension in a rat model of the metabolic syndrome. Metab Syndr Relat Disord 7: 327-334. 
24. Yu M, Moreno C, Hoagland KM, Dahly A, Ditter K, et al. (2003) Antihypertensive effect of glucagon-like peptide 1 in Dahl salt-sensitive rats. J Hypertens 21: 1125-1135.

25. Yamamoto H, Lee CE, Marcus JN, Williams TD, Overton JM, et al. (2002) Glucagon-like peptide-1 receptor stimulation increases blood pressure and heart rate and activates autonomic regulatory neurons. J Clin Invest 110: 4352.

26. Liu Q, Adams L, Broyde A, Fernandez R, Baron AD, et al. (2010) The exenatide analogue AC3174 attenuates hypertension, insulin resistance, and renal dysfunction in Dahl salt-sensitive rats. Cardiovasc Diabetol 9: 32.

27. Bose AK, Mocanu MM, Carr RD, Brand CL, Yellon DM (2005) Glucagon-like peptide 1 can directly protect the heart against ischemia/reperfusion injury. Diabetes 54: 146-151.

28. Nikolaidis LA, Doverspike A, Hentosz T, Zourelias L, Shen YT, et al. (2005) Glucagon-like peptide-1 limits myocardial stunning following brief coronary occlusion and reperfusion in conscious canines. J Pharmacol Exp Ther 312: 303-308

29. Noyan-Ashraf MH, Momen MA, Ban K, Sadi AM, Zhou YQ, et al. (2009) GLP-1R agonist liraglutide activates cytoprotective pathways and improves outcomes after experimental myocardial infarction in mice. Diabetes 58: 975-983.

30. Sonne DP, Engstrøm T, Treiman M (2008) Protective effects of GLP-1 analogues exendin-4 and GLP-1(9-36) amide against ischemia-reperfusion injury in rat heart. Regul Pept 146: 243-249.

31. Timmers L, Henriques JP, de Kleijn DP, Devries JH, Kemperman H, et al. (2009) Exenatide reduces infarct size and improves cardiac function in a porcine model of ischemia and reperfusion injury. J Am Coll Cardiol 53: 501510 .

32. Zhao T, Parikh P, Bhashyam S, Bolukoglu H, Poornima I, et al. (2006) Direct effects of glucagon-like peptide-1 on myocardial contractility and glucose uptake in normal and postischemic isolated rat hearts. J Pharmacol Exp Ther 317: 1106-1113.

33. Dokken BB, La Bonte LR, Davis-Gorman G, Teachey MK, Seaver N, et al. (2011) Glucagon-like peptide-1 (GLP-1), immediately prior to reperfusion, decreases neutrophil activation and reduces myocardial infarct size in rodents. Hormone and metabolic research $=$ Hormon- und Stoffwechselforschung = Hormones et metabolisme 43: 300-305.

34. Gotfredsen CF, Mølck AM, Thorup I, Nyborg NC, Salanti Z, et al. (2014) The human GLP-1 analogs liraglutide and semaglutide: absence of histopathological effects on the pancreas in nonhuman primates. Diabetes 63: 2486-2497.

35. Luo X, Pan L, Nie A, Wang Q, Gu Y, et al. (2013) Liraglutide protects pancreatic beta cells during an early intervention in Gato-Kakizaki rats. J Diabetes 5: 421428.

36. Koehler JA, Baggio LL, Cao X, Abdulla T, Campbell JE, et al. (2014) Glucagonlike peptide-1 receptor agonists increase pancreatic mass by induction of protein synthesis. Diabetes

37. Ravassa S, Zudaire A, Díez J (2012) GLP-1 and cardioprotection: from bench to bedside. Cardiovasc Res 94: 316-323.

38. Clarke SJ, McCormick LM, Dutka DP (2014) Optimising cardioprotection during myocardial ischaemia: targeting potential intracellular pathways with glucagonlike peptide-1. Cardiovasc Diabetol 13: 12

39. Ishibashi Y, Nishino Y, Matsui T, Takeuchi M, Yamagishi S (2011) Glucagonlike peptide-1 suppresses advanced glycation end product-induced monocyte chemoattractant protein-1 expression in mesangial cells by reducing advanced glycation end product receptor level. Metabolism 60: 1271-1277.

40. Ishibashi Y, Matsui T, Takeuchi M, Yamagishi S (2010) Glucagon-like peptide-1 (GLP-1) inhibits advanced glycation end product (AGE)-induced up-regulation of VCAM-1 mRNA levels in endothelial cells by suppressing AGE receptor (RAGE) expression. Biochem Biophys Res Commun 391: 1405-1408.

41. Kim M, Platt MJ, Shibasaki T, Quaggin SE, Backx PH, et al. (2013) GLP-1 receptor activation and Epac2 link atrial natriuretic peptide secretion to control of blood pressure. Nat Med 19: 567-575

42. Arakawa M, Mita T, Azuma K, Ebato C, Goto H, et al. (2010) Inhibition of monocyte adhesion to endothelial cells and attenuation of atherosclerotic lesion by a glucagon-like peptide- 1 receptor agonist, exendin-4. Diabetes 59: 1030-1037.

43. Drucker DJ, Buse JB, Taylor K, Kendall DM, Trautmann M, et al. (2008)
Exenatide once weekly versus twice daily for the treatment of type 2 diabetes: a randomised, open-label, non-inferiority study. Lancet 372: 1240-1250.

44. Bergenstal RM, Wysham C, Macconell L, Malloy J, Walsh B, et al. (2010) Efficacy and safety of exenatide once weekly versus sitagliptin or pioglitazone as an adjunct to metformin for treatment of type 2 diabetes (DURATION-2): a randomised trial. Lancet 376: 431-439.

45. Diamant M, Van Gaal L, Stranks S, Northrup J, Cao D, et al. (2010) Once weekly exenatide compared with insulin glargine titrated to target in patients with type 2 diabetes (DURATION-3): an open-label randomised trial. Lancet 375: 2234-2243

46. Buse JB, Nauck M, Forst T, Sheu WH, Shenouda SK, et al. (2013) Exenatide once weekly versus liraglutide once daily in patients with type 2 diabetes (DURATION-6): a randomised, open-label study. Lancet 381: 117-124.

47. Blevins T, Pullman J, Malloy J, Yan P, Taylor K, et al. (2011) DURATION-5: exenatide once weekly resulted in greater improvements in glycemic control compared with exenatide twice daily in patients with type 2 diabetes. $\mathrm{J}$ Clin Endocrinol Metab 96: 1301-1310.

48. Russell-Jones D, Cuddihy RM, Hanefeld M, Kumar A, González JG, et al. (2012) Efficacy and safety of exenatide once weekly versus metformin pioglitazone, and sitagliptin used as monotherapy in drug-naive patients with type 2 diabetes (DURATION-4): a 26-week double-blind study. Diabetes Care 35: 252-258.

49. Diamant M, Van Gaal L, Stranks S, Guerci B, MacConell L, et al. (2012) Safety and efficacy of once-weekly exenatide compared with insulin glargine titrated to target in patients with type 2 diabetes over 84 weeks. Diabetes Care 35 : 683-689.

50. Diamant M, Van Gaal L, Guerci B, Stranks S, Han J, et al. (2014) Exenatide once weekly versus insulin glargine for type 2 diabetes (DURATION-3): 3-year results of an open-label randomised trial. Lancet Diabetes Endocrinol 2: 464 473.

51. Buse JB, Drucker DJ, Taylor KL, Kim T, Walsh B, et al. (2010) DURATION-1 exenatide once weekly produces sustained glycemic control and weight loss over 52 weeks. Diabetes Care 33: 1255-1261.

52. MacConell L, Pencek R, Li Y, Maggs D, Porter L (2013) Exenatide once weekly: sustained improvement in glycemic control and cardiometabolic measures through 3 years. Diabetes, metabolic syndrome and obesity : targets and therapy $6: 31-41$.

53. Blonde L, Russell-Jones D (2009) The safety and efficacy of liraglutide with or without oral antidiabetic drug therapy in type 2 diabetes: an overview of the LEAD 1-5 studies. Diabetes Obes Metab 11 Suppl 3: 26-34.

54. Buse JB, Sesti G, Schmidt WE, Montanya E, Chang CT, et al. (2010) Switching to once-daily liraglutide from twice-daily exenatide further improves glycemic control in patients with type 2 diabetes using oral agents. Diabetes Care 33: 1300-1303.

55. Buse JB, Rosenstock J, Sesti G, Schmidt WE, Montanya E, et al. (2009) Liraglutide once a day versus exenatide twice a day for type 2 diabetes: a 26-week randomised, parallel-group, multinational, open-label trial (LEAD-6). Lancet 374: 39-47.

56. Garber A, Henry RR, Ratner R, Hale P, Chang CT, et al. (2011) Liraglutide a once-daily human glucagon-like peptide 1 analogue, provides sustained improvements in glycaemic control and weight for 2 years as monotherapy compared with glimepiride in patients with type 2 diabetes. Diabetes Obes Metab 13: 348-356.

57. Garber A, Henry R, Ratner R, Garcia-Hernandez PA, Rodriguez-Pattzi H, et al (2009) Liraglutide versus glimepiride monotherapy for type 2 diabetes (LEAD-3 Mono): a randomised, 52-week, phase III, double-blind, parallel-treatment trial. Lancet 373: 473-481.

58. Marre M, Shaw J, Brändle M, Bebakar WM, Kamaruddin NA, et al. (2009) Liraglutide, a once-daily human GLP-1 analogue, added to a sulphonylurea over 26 weeks produces greater improvements in glycaemic and weight contro compared with adding rosiglitazone or placebo in subjects with Type 2 diabetes (LEAD-1 SU). Diabet Med 26: 268-278.

59. Nauck M, Frid A, Hermansen K, Shah NS, Tankova T, et al. (2009) Efficacy and safety comparison of liraglutide, glimepiride, and placebo, all in combination with metformin, in type 2 diabetes: the LEAD (liraglutide effect and action in diabetes)-2 study. Diabetes Care 32: 84-90.

60. Russell-Jones D, Vaag A, Schmitz O, Sethi BK, Lalic N, et al. (2009) Liraglutide 
vs insulin glargine and placebo in combination with metformin and sulfonylurea therapy in type 2 diabetes mellitus (LEAD- 5 met+SU): a randomised controlled trial. Diabetologia 52: 2046-2055.

61. Apovian CM, Bergenstal RM, Cuddihy RM, Qu Y, Lenox S, et al. (2010) Effects of exenatide combined with lifestyle modification in patients with type 2 diabetes. Am J Med 123: 468

62. Davies MJ, Donnelly R, Barnett AH, Jones S, Nicolay C, et al. (2009) Exenatide compared with long-acting insulin to achieve glycaemic control with minima weight gain in patients with type 2 diabetes: results of the Helping Evaluate Exenatide in patients with diabetes compared with Long-Acting insulin (HEELA) study. Diabetes Obes Metab 11: 1153-1162.

63. Davies M, Heller S, Sreenan S, Sapin H, Adetunji O, et al. (2013) Once-weekly exenatide versus once- or twice-daily insulin detemir: randomized, open-label, clinical trial of efficacy and safety in patients with type 2 diabetes treated with metformin alone or in combination with sulfonylureas. Diabetes Care 36: 13681376.

64. Klonoff DC, Buse JB, Nielsen LL, Guan X, Bowlus CL, et al. (2008) Exenatide effects on diabetes, obesity, cardiovascular risk factors and hepatic biomarkers in patients with type 2 diabetes treated for at least 3 years. Curr Med Res Opin 24: $275-286$

65. Moretto TJ, Milton DR, Ridge TD, Macconell LA, Okerson T, et al. (2008) Efficacy and tolerability of exenatide monotherapy over 24 weeks in antidiabetic drug-naive patients with type 2 diabetes: a randomized, double-blind, placebocontrolled, parallel-group study. Clin Ther 30: 1448-1460

66. Pratley RE, Nauck M, Bailey T, Montanya E, Cuddihy R, et al. (2010) Liraglutide versus sitagliptin for patients with type 2 diabetes who did not have adequate glycaemic control with metformin: a 26-week, randomised, parallel-group, open-label trial. Lancet 375: 1447-1456.

67. Pratley R, Nauck M, Bailey T, Montanya E, Cuddihy R, et al. (2011) One year of liraglutide treatment offers sustained and more effective glycaemic control and weight reduction compared with sitagliptin, both in combination with metformin, in patients with type 2 diabetes: a randomised, parallel-group, open-label trial Int J Clin Pract 65: 397-407.

68. Umpierrez G, Tofé Povedano S, Pérez Manghi F, Shurzinske L, Pechtner V (2014) Efficacy and safety of dulaglutide monotherapy versus metformin in type 2 diabetes in a randomized controlled trial (AWARD-3). Diabetes Care 37: 2168-2176.

69. Nauck M, Weinstock RS, Umpierrez GE, Guerci B, Skrivanek Z, et al. (2014) Efficacy and safety of dulaglutide versus sitagliptin after 52 weeks in type 2 diabetes in a randomized controlled trial (AWARD-5). Diabetes Care 37: 21492158.

70. Wysham C, Blevins T, Arakaki R, Colon G, Garcia P, et al. (2014) Efficacy and safety of dulaglutide added onto pioglitazone and metformin versus exenatide in type 2 diabetes in a randomized controlled trial (AWARD-1). Diabetes Care 37: $2159-2167$

71. Dungan KM, Povedano ST, Forst T, González JG, Atisso C, et al. (2014) Onceweekly dulaglutide versus once-daily liraglutide in metformin-treated patients with type 2 diabetes (AWARD-6): a randomised, open-label, phase 3 , noninferiority trial. Lancet 384: 1349-1357.

72. Ahren B, Johnson SL, Stewart M, Cirkel DT, Yang F, et al. (2014) HARMONY 3: 104-week randomized, double-blind, placebo- and active-controlled tria assessing the efficacy and safety of albiglutide compared with placebo, sitagliptin, and glimepiride in patients with type 2 diabetes taking metformin Diabetes Care 37: 2141-2148.

73. Pratley RE, Nauck MA, Barnett AH, Feinglos MN, Ovalle F, et al. (2014) Onceweekly albiglutide versus once-daily liraglutide in patients with type 2 diabetes inadequately controlled on oral drugs (HARMONY 7): a randomised, openlabel, multicentre, non-inferiority phase 3 study. Lancet Diabetes Endocrino 2: 289-297.

74. Weissman PN, Carr MC, Ye J, Cirkel DT, Stewart M, et al. (2014) HARMONY 4 randomised clinical trial comparing once-weekly albiglutide and insulin glargine in patients with type 2 diabetes inadequately controlled with metformin with or without sulfonylurea. Diabetologia 57: 2475-2484.

75. Terauchi $Y$, Satoi $Y$, Takeuchi M, Imaoka T (2014) Monotherapy with the once weekly GLP-1 receptor agonist dulaglutide for 12 weeks in Japanese patients with type 2 diabetes: dose-dependent effects on glycaemic control in a randomised, double-blind, placebo-controlled study. Endocr J 61: 949-959.

76. Rosenstock J, Hanefeld M, Shamanna P, Min KW, Boka G, et al. (2014)
Beneficial effects of once-daily lixisenatide on overall and postprandial glycemic levels without significant excess of hypoglycemia in type 2 diabetes inadequately controlled on a sulfonylurea with or without metformin (GetGoal-S). J Diabetes Complications 28: 386-392.

77. Rosenstock J, Raccah D, Korányi L, Maffei L, Boka G, et al. (2013) Efficacy and safety of lixisenatide once daily versus exenatide twice daily in type 2 diabetes inadequately controlled on metformin: a 24-week, randomized, open-label, active-controlled study (GetGoal-X). Diabetes Care 36: 2945-2951.

78. Yu Pan C, Han P, Liu X, Yan S, Feng P, et al. (2014) Lixisenatide treatmen improves glycaemic control in Asian patients with type 2 diabetes mellitus inadequately controlled on metformin with or without sulfonylurea: A randomized, double-blind, placebo-controlled, 24-week trial (GetGoal-M-Asia). Diabetes Metab Res Rev doi: 10.1002/dmrr.2541 [Epub ahead of print].

79. Okerson T, Yan P, Stonehouse A, Brodows R (2010) Effects of exenatide on systolic blood pressure in subjects with type 2 diabetes. Am J Hypertens 23 334-339.

80. Meloni AR, DeYoung MB, Han J, Best JH, Grimm M (2013) Treatment of patients with type 2 diabetes with exenatide once weekly versus oral glucose-lowering medications or insulin glargine: achievement of glycemic and cardiovascular goals. Cardiovasc Diabetol 12: 48.

81. Fonseca VA, Devries JH, Henry RR, Donsmark M, Thomsen HF, et al. (2014) Reductions in systolic blood pressure with liraglutide in patients with type 2 diabetes: insights from a patient-level pooled analysis of six randomized clinical trials. J Diabetes Complications 28: 399-405

82. Chilton RJ, MacConell LA, Han J, Marso SP (2013) Characterization of heart rate increases with glucagon-like peptide-1 receptor agonist therapy [poster]

83. Chiquette E, Toth PP, Ramirez G, Cobble M, Chilton R (2012) Treatment with exenatide once weekly or twice daily for 30 weeks is associated with changes in several cardiovascular risk markers. Vasc Health Risk Manag 8: 621-629.

84. Inagaki N, Atsumi Y, Oura T, Saito H, Imaoka T (2012) Efficacy and safety profile of exenatide once weekly compared with insulin once daily in Japanese patients with type 2 diabetes treated with oral antidiabetes drug(s): results from a 26-week, randomized, open-label, parallel-group, multicenter, noninferiority study. Clin Ther 34: 1892-1908 e1891.

85. Kadowaki T, Namba M, Yamamura A, Sowa H, Wolka AM, et al. (2009) Exenatide exhibits dose-dependent effects on glycemic control over 12 weeks in Japanese patients with suboptimally controlled type 2 diabetes. Endocr $J$ 56: $415-424$

86. Seino Y, Rasmussen MF, Nishida T, Kaku K (2010) Efficacy and safety of the once-daily human GLP-1 analogue, liraglutide, vs glibenclamide monotherapy in Japanese patients with type 2 diabetes. Curr Med Res Opin 26: 1013-1022.

87. Linnebjerg H, Seger M, Kothare PA, Hunt T, Wolka AM, et al. (2011) A thorough QT study to evaluate the effects of singledose exenatide $10 \hat{1} 1 / 4 \mathrm{~g}$ on cardiac repolarization in healthy subjects. Int J Clin Pharmacol Ther 49: 594-604.

88. Darpö B, Sager P, MacConell L, Cirincione B, Mitchell M, et al. (2013) Exenatide at therapeutic and supratherapeutic concentrations does not prolong the QTC interval in healthy subjects. Br J Clin Pharmacol 75: 979-989.

89. Chatterjee DJ, Khutoryansky N, Zdravkovic M, Sprenger CR, Litwin JS (2009) Absence of QTc prolongation in a thorough QT study with subcutaneous liraglutide, a once-daily human GLP-1 analog for treatment of type 2 diabetes. $\mathrm{J}$ Clin Pharmacol 49: 1353-1362.

90. Darpo B, Zhou M, Matthews J, Zhi H, Young MA, et al. (2014) Albiglutide does not prolong QTc interval in healthy subjects: a thorough ECG study. Diabetes Ther 5: 141-153.

91. Lønborg J, Vejlstrup N, Kelbæk H, Bøtker HE, Kim WY, et al. (2012) Exenatide reduces reperfusion injury in patients with ST-segment elevation myocardia infarction. Eur Heart J 33: 1491-1499.

92. Lonborg J, Vejlstrup N, Kelbaek H, Nepper-Christensen L, Jorgensen E, et al. (2014) Impact of acute hyperglycemia on myocardial infarct size, area at risk, and salvage in patients with STEMI and the association with exenatide treatment: results from a randomized study. Diabetes 63: 2474-2485.

93. Woo JS, Kim W, Ha SJ, Kim JB, Kim SJ, et al. (2013) Cardioprotective effects of exenatide in patients with ST-segment-elevation myocardial infarction undergoing primary percutaneous coronary intervention: results of exenatide myocardial protection in revascularization study. Arteriosclerosis, thrombosis and vascular biology 33: 2252-2260. 
Citation: Chilton RJ (2015) Potential Cardiovascular Effects of the Glucagon-like Peptide-1 Receptor Agonists. J Diabetes Metab 6: 483. doi:10.4172/2155-6156.1000483

94. Bunck MC, Diamant M, Eliasson B, Cornér A, Shaginian RM, et al. (2010) Exenatide affects circulating cardiovascular risk biomarkers independently of changes in body composition. Diabetes Care 33: 1734-1737.

95. Derosa G, Maffioli P, Salvadeo SA, Ferrari I, Ragonesi PD, et al. (2010) Exenatide versus glibenclamide in patients with diabetes. Diabetes Technol Ther 12: 233-240.

96. Courrèges JP, Vilsbøll T, Zdravkovic M, Le-Thi T, Krarup T, et al. (2008) Beneficial effects of once-daily liraglutide, a human glucagon-like peptide-1 analogue, on cardiovascular risk biomarkers in patients with Type 2 diabetes. Diabet Med 25: 1129-1131.

97. Bunck MC, Diamant M, Corner A, Eliasson B, Malloy JL, et al. (2009) One-year treatment with exenatide improves beta-cell function, compared with insulin glargine, in metformin-treated type 2 diabetic patients: a randomized, controlled trial. Diabetes Care 32: 762-768.

98. Ratner R, Han J, Nicewarner D, Yushmanova I, Hoogwerf BJ, et al. (2011) Cardiovascular safety of exenatide BID: an integrated analysis from controlled clinical trials in participants with type 2 diabetes. Cardiovasc Diabetol 10: 22.

99. Gaede P, Lund-Andersen H, Parving HH, Pedersen O (2008) Effect of a multifactorial intervention on mortality in type 2 diabetes. N Engl J Med 358: 580-591.
100.Boden WE, O'Rourke RA, Teo KK, Hartigan PM, Maron DJ, et al. (2007) Optimal medical therapy with or without $\mathrm{PCl}$ for stable coronary disease. $\mathrm{N}$ Engl J Med 356: 1503-1516.

101.Bernink FJ, Timmers L, Diamant M, Scholte M, Beek AM, et al. (2013) Effect of additional treatment with EXenatide in patients with an Acute Myocardial Infarction: the EXAMI study. International journal of cardiology 167: 289-290.

102. Scholte M, Timmers L, Bernink FJ, Denham RN, Beek AM, et al. (2011) Effect of additional treatment with EXenatide in patients with an Acute Myocardia Infarction (EXAMI): study protocol for a randomized controlled trial. Trials 12: 240.

103. Anholm C, Kumarathurai P, Klit MS, Kristiansen OP, Nielsen OW, et al (2014) Adding liraglutide to the backbone therapy of biguanide in patients with coronary artery disease and newly diagnosed type-2 diabetes (the AddHope2 study): a randomised controlled study protocol. BMJ Open 4: e005942.

104. Jorsal A, Wiggers $H$, Holmager P, Nilsson B, Nielsen R, et al. (2014) A protocol for a randomised, double-blind, placebo-controlled study of the effect of LIraglutide on left VEntricular function in chronic heart failure patients with and without type 2 diabetes (The LIVE Study). BMJ Open 4: e004885. 